\title{
EFFECT OF LIVELIHOOD DIVERSIFICATION AND TECHNOLOGY ADOPTION ON FOOD SECURITY STATUS OF RICE FARMING HOUSEHOLDS IN OGUN STATE. NIGERIA
}

\author{
Afodu Osagie John ${ }^{1 *}$, Afolami Carolyn Afolake ${ }^{1,2}$, Balogun Olubunmi \\ Lawrence ${ }^{1}$ \\ ${ }^{1}$ Department of Agriculture and Industrial Technology, School of Science and Technology, Babcock University, \\ Ogun State, Nigeria. \\ ${ }^{2}$ Department of Agricultural Economics, College of Agricultural Management and Rural Development, Federal \\ University of Agriculture Abeokuta, Ogun State, Nigeria. \\ *corresponding author: afoduo@babcock.edu.ng
}

\begin{abstract}
This study assesses the effect of livelihood diversification and technology adoption on food security status among rice farming households in the Ogun State Nigeria. Farming households in Africa have increasingly sought means of escaping from the detrimental consequences of poverty by inclining to diversification of their activities; within and outside the farm sector. A multistage sampling technique was used to select 158 rice farmers. A well-structured questionnaire was used to collect data for the study. The data were analyzed using descriptive statistics, Simpson Index, adoption index and logit regression model. Factors affecting food security of the rice farmers were Simpson Index of Diversification $\left(\gamma_{1}=0.320, p=5 \%\right)$, Technologies Adoption Index $\left(\gamma_{2}=1.019\right.$, $\mathrm{p}=5 \%)$, household size $\left(\gamma_{5}=-0.060, \mathrm{p}=10 \%\right)$, educational status of the farmers $\left(\gamma_{6}=0.035, \mathrm{p}=5 \%\right)$, farm size $\left(\gamma_{7}=\right.$ $0.133, p=5 \%)$ and access to credit $\left(\gamma_{9}=0.405, p=10 \%\right)$. It was recommended that rice farmers should be educated on modern technologies in rice production. Credit facilities should be made available for the rice farming household either by the government or private organizations to enhance farming activities, alleviate poverty and increase household food security.
\end{abstract}

Keywords: Diversification, Farming Households, Food Security Status, Livelihood, Rice, Technology Adoption http://dx.doi.org/10.21776/ub.agrise.2020.020.3.7

\section{INTRODUCTION}

Farming as a livelihood activity is associated with immense risks (climate, pest and diseases, price and policy). This phenomenon is more severe in SubSaharan African countries including Nigeria where appropriate lasting mitigation solutions have yielded average results. Farming households (households who engage in the production of crops and or livestock) in Africa have increasingly sought means of escaping from the detrimental consequences of poverty by inclining to diversification of their activities; within and outside the farm sector. This is to primarily address their income and food security shortfalls (Barrett \& Reardon, 2000; Korir et al., 2005). Diversification therefore supports farm households to accumulate income for farm expansion and engagement in non-farm businesses (Dimova \& Sen, 2010; Lay and Schuler, 2008) and to solve immediate household needs (food, shelter, health care and payment of school fees).

Ellis (2000a) defined livelihood diversification 
as a process by which rural households construct an increasingly diverse portfolio of activities and assets in order to survive and improve their standard of living. Therefore, an analysis of the diversification concept empirically, has been assessed from the asset, income or activity viewpoints. Asset measurement is deemed arduous and sometimes crudely estimated due to the poor development of asset market especially in most rural communities in Africa (Barrett \& Reardon, 2000). Drawing on Minot et al. (2006), Ronning \& Koveried (2006), this study defines income diversification as "a situation where farm households rely on income from multiple sources; both farm and non-farm". Income diversification is commonly specified in conformity with the standard practice of national accounting and macro input/output table construction where separation is made among sectoral, functional and locational or spatial (migration influences) classifications of diversification.

For rural households, the ability to produce and feed its members relies on being able to farm or acquire from other sources which in turn depends on the possession of assets like skills, farmland, finance, market, and social networks. The contribution of non-agricultural activities to household income in the developing world in general and Sub-Saharan Africa in particular is substantial. Local non-farming income contributes between 30 to $40 \%$ of rural household income in the developing world (Haggblade el al, 2007). Various studies have shown that while most rural households are involved in agricultural activities such as livestock, crop, or fish production as their main source of livelihood, they also engage in other income generating activities to augment their main source of income (Adepoju and Obayelu, 2013).

The focus on livelihood is relevant, in particular with the discussion on rural poverty reduction. With prevalent poverty in most rural areas, rural development has been an important policy goal for many developing countries, and large-scale, structural reform measures have been taken to this end (Hyewon, 2011). The growing interest in research on rural off-farm and non-farm income in rural economies shows that rural people's livelihoods are derived from diverse sources and are not as overwhelmingly dependent on agriculture as previously assumed (Gordon and Craig, 2001). Nonfarm local activities include all economic activities in rural areas except agriculture, livestock, fishing and hunting. It includes all off-farming activities, processing, marketing, manufacturing, wage and causal local employment in the rural villages (Agu, 2013).

One of the major goals of Nigerian agricultural development programs and policies is transition from low productivity subsistence agriculture to a high productivity agro-industrial economy through improved technology adoption. That is, shift from traditional methods of production to new, sciencebased methods of production which include new technological components and/or even new farming systems (Hassen, 2015). Solving environmental problems in agriculture requires developing and diffusing new technologies (Viatte, 2001). As huge number of the poor lives in rural areas and are engaged in smallholding agriculture, attempt to address the rural poor are often geared toward improving agricultural practices as a means of increasing productivity, efficiency and, finally income. Agricultural technology aims at increasing agricultural productivity by replacing the old method of farming by a modern and more efficient technique of cultivation (Barla, 2013).

The majority of world's food insecure are rural smallholder farmers, and inhabit the developing world (UNECA 2013; Hazell 2011; RPR 2011). About 23.8 percent of food insecure people worldwide live in Sub-Saharan Africa (SSA) (FAO, WFP, and IFAD, 2014). Of this proportion, 80 percent live in rural areas, working as peasants, landless laborers and pastoralists which are often labeled with resource dearth (Rural Poverty Report, 2011).

Agriculture is the main livelihood strategy in developing countries. It absorbs a huge rural labor, generates a significant share of Gross Domestic Product (GDP) and is a crucial sector to address food security (Hazell 2011; Boto 2014). However, agriculture in Sub-Saharan Africa is dependent on variable climate. In addition to this, farmers in Africa live on small hectare of farmland. Decimation of farm size accelerates and hence thwarts efforts to increase farm productivity. Therefore, in line with augmenting agricultural productivity, looking for other ways out has been put forward as an equally potent strategy for addressing household food security (Stifel 2010; Asmah 2011; Maharjan, 2014).

In general, food security is defined as a condition "when all people, at all times, have physical, social, and economic access to sufficient, safe, and nutritious food to meet their dietary needs and food preferences for an active and healthy life" (FAO, 2015). This means that food security includes freedom from both famine and chronic malnutrition. Also, about 795 million people are estimated to be undernourished globally (FAO, IFAD, WFP, 2015). Bonnard (1999) identified food security to incorporate four major elements namely, food availability, food accessibility, utilization and stability of food access.

Rice (oryza sativa) as a crop has received widespread attention from International and regional bodies due to its importance. Research work continues to go on to develop better varieties of the crop suited to a particular climate. In West Africa, under the umbrella of the West African Rice 
Development Authority (WARDA), some countries of West Africa of which Nigeria is one, are carrying out intensive research and promotion of the cultivation of the coarse grains (FAO, 2017). It is a preferred food in urban centers of many countries including Nigeria (Igbokwe, 2001) and in institutions, because of the relative ease of preparation in catering for large numbers of people (Akande, 2002). In Nigeria, its importance is seen in the fact that it is accepted amongst all cultures (Okeke et al., 2008; Onimawo, 2012), and is normally preferably prepared in social functions.

\section{MATERIALS AND METHODS}

The study was conducted in Ogun State southwest of Nigeria. It lies between latitude $6^{\circ} 54^{\prime} 35.4^{\prime \prime} \mathrm{N}$ of the equator and longitude $3^{\circ} 15^{\prime} 30.11^{\prime \prime} \mathrm{E}$ of the Greenwich meridian (Tawan 2006). Ogun State is made up of four Agricultural Development Programme zones, namely; Ilaro zone, Ikenne zone, Abeokuta zone and Ijebu ode zone. The state has a land area of 16,980 sq. $\mathrm{km}$, a population of 3,751,140 people (National Population Commission, 2006). The state has twenty Local Government Area's, and the vegetation is evergreen forests and savanna. The major crops grown in the state are cocoa, oil palm, rice, cassava, cotton and vegetables. Below is the map of Ogun State showing the four Agricultural Development Programme zones.

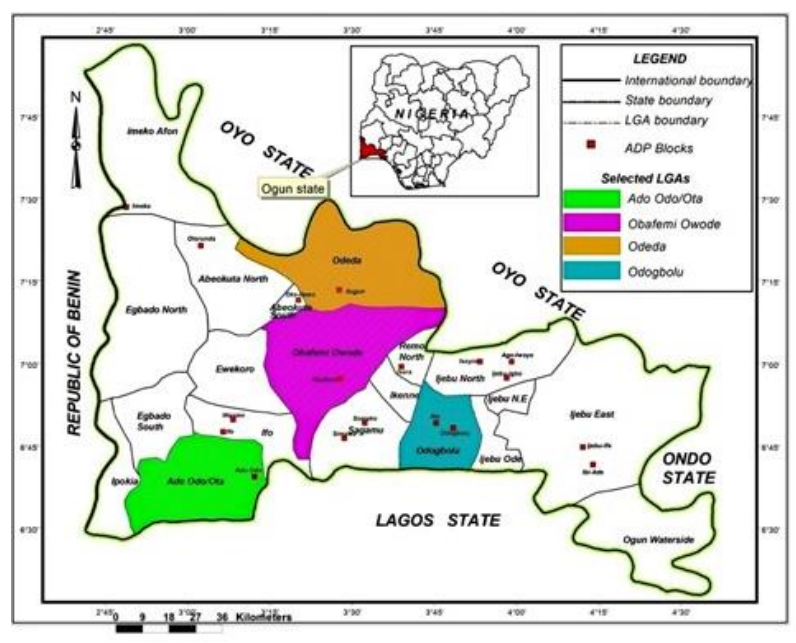

Figure. 1: Map of Ogun State

Primary data were used for this study. Data collected were on households' demographic and socioeconomic characteristics such as age, educational level, marital status, sex, income, household size as well as data on food security viz the types of food, the quantity and quality of food items consumed in the previous seven days to the time of the interview, access to credit, total expenditure on food and access to public health services. Also, data were collected on sources of livelihoods and on technologies used in rice farming. The data were collected through the administration of a well-structured questionnaire on a cross-section of surveyed rice farmers in the study area.

A multistage sampling technique was used for this study for selection of rice farmers. The first stage involved purposive selection of two Agricultural Development Programme zones namely Ikenne and Abeokuta. These two ADP zones were selected because of the concentration of rice farmers in this area.

The second stage was the purposive selection of two blocks per zone based on the concentration of rice farmers. Thirdly, six farming cells were randomly selected from each of the block making a total of twenty-four (24) farming cells. Lastly, seven rice farmers were randomly selected from each farming cell giving a total sample size of 168 rice farmers.

\section{METHOD OF DATA ANALYSIS}

The analytical tools employed in this study were descriptive and inferential statistics. The descriptive statistical tools used were frequency, percentages, Simpson Index for livelihood diversification was used to investigate the degree of livelihood diversification. Adoption index was computed for technologies adopted, while Logit regression models was used for analyzing the determinants of food security

The Simpsons Index of Diversity (SID) was used in this study to estimate the degree of income diversification among rice farmers in Ogun State. The SID takes into consideration both the number of income sources as well as how evenly the distributions of the income were between the different sources (Minot et al., 2006). The SID ranges between zero (0) and one (1). A value of 0 denotes specialization and 1 the extremity of diversification. The closer the SID value is to one, the more diversified the household is considered The SID general formula is given as:

$\mathrm{SID}=1-\Sigma_{\mathrm{i}}^{\mathrm{n}} \mathrm{P}_{\mathrm{i}}^{2}$

$\mathrm{SID}=$ Simpsons Index of Diversification, $\mathrm{n}=$ number of income sources, $\mathrm{P}_{\mathrm{i}}=$ Proportion of income coming from the source $i$. The value of SID ranges between zero (0) and one (1) However, if there is only one source of income, $\mathrm{P}_{\mathrm{i}}=1$, and $\mathrm{SID}=0$.

The SID model is expressed as: 


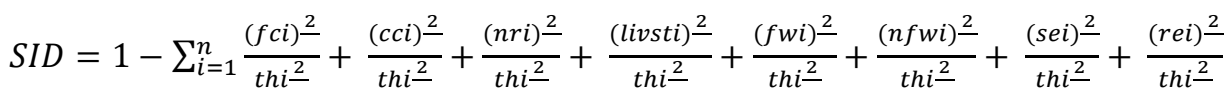

Where:

$\mathrm{fc}_{\mathrm{i}}=$ food crops income,

$\mathrm{cc}_{\mathrm{i}}=$ cash crops income,

$\mathrm{nr}_{\mathrm{i}}=$ natural resource income,

Livsti=Livestock income,

$\mathrm{fw}_{\mathrm{i}}=$ farm wage income,

$\mathrm{nfw}_{\mathrm{i}}=$ Non-farm wage income,

$\mathrm{se}_{\mathrm{i}}=$ self-employment income,

$\mathrm{re}_{\mathrm{i}}=$ remittance income,

others $\mathrm{s}_{\mathrm{i}}=$ other income sources.

$\mathrm{n}$ = number of income sources.

The value of the index is zero when there is a complete specialization and approaches one as the level of diversification increases.

\section{Estimation of the Adoption index}

In this study, the adoption index is specified in equation 7 following Mihiretu (2008), Ayalew (2011) and Obayelu et al., (2016), was used to measure the extent of technology adoption at the time of the survey for multiple practices, which shows to what extent the respondent has adopted the most set of technology.

$$
A l_{i}=\sum \frac{\left[\frac{A H_{i}}{A T_{i}}+\frac{S R A_{i}}{S R R}+\frac{F A_{i}}{F R}+--------N\right]}{N P}
$$

Where:

$\mathrm{AI} i=$ Adoption index $\mathrm{i}$ of respondents (which ranges between 0 and 1 )

$A H=$ area under improved variety of rice of the ith farmer.

$A T i=$ Total area allocated for rice production (improved variety+ local, if any) of the ith farmer.

$S R A i=$ Seeding rate applied per unit of area in the production of improved variety of the selected crop of ith farmer.

$\mathrm{S} R R=$ Seeding rate recommended for application per unit of area.

$F A i=$ amount of fertilizer applied per unit of area in the cultivation of improved variety of rice by ith farmer,

$F R i=$ Amount of fertilizer recommended for application per unit of area in the cultivation of improved variety of rice,

$N P=$ Number of practices

Food Security Status of Rice Farming Household Household Expenditure Survey Method (HESM) was adopted for this study to capture the food security status of the respondents, this is because this tool requires getting information about the quantity of food bought and expenditures on different food types (items) consumed within and outside the house. For instance, we computed the total household expenditure as a proxy for total household income and food expenditure share following Adenegan and Adewusi (2007), Babatunde et al. (2007), Omonona and Agoi (2007), Arene and Anyaeji (2010), Oni et al. (2011), Tshediso (2013)

Food security status among rice farming households was assessed using Foster, Greer and Thorbecke- FGT (1984) model. The Foster, Greer and Thorbecke- FGT (1984) model is specified as follows:
$P_{a}=\frac{1}{n} \sum_{i-1}^{q} G i$

Where,

$G i=\left[\frac{Z-Y}{Z}\right]$

$=$ food expenditure deficiency of household $i$

Head count ratio $(\mathrm{H})=\mathrm{q} / \mathrm{n}$

$\mathrm{Z}=$ food security line $(2 / 3$ mean per equivalent food expenditure)

$\mathrm{Y}=$ the per capita equivalent food expenditure of household i,

$\alpha=$ the degree of food insecurity aversion; $\alpha=0$ measures the incidence of insecurity.

$\alpha=1$ measures the depth of food insecurity. $\alpha=2$ measure the severity of food insecurity.

$\mathrm{q}=$ the number of rice farm households below the food security line.

$\mathrm{n}=$ the total number of rice farm households in the sample,

$\mathrm{P}_{\alpha}=$ degree to which a household is food secure

Logit regression was adopted to analyze the effect of livelihood diversification, technology adoption on farming household food security status. The model is specified as:

$Y_{i}=\gamma_{0}+\sum \gamma_{\mathrm{j}} \mathrm{x}_{\mathrm{j}}+\varepsilon_{\mathrm{j}}$

$Y_{i}=\gamma_{0}+\gamma_{1}$ SID $+\gamma_{2}$ TAI $+\gamma_{3}$ age $+\gamma_{4}$ sex $+\gamma_{5}$ hhs + $\gamma_{6}$ edu $+\gamma_{7}$ farsize $+\gamma_{8}$ coopmem $+\gamma_{9}$ accesstocre + $\gamma_{10}$ marital $+\gamma_{11}$ ext.visit $+\gamma_{12}$ acccredit $+\varepsilon_{i}$

Where:

$Y_{i} \quad=$ Food Security Status [ Food Secure

$=1$, Non-Food Secure $=0$

SID $\quad=$ Simpson Index of Diversification

TAI = Technology Adoption Index

Age $\quad=$ Age of the Rice Farmers [in years] Sex $[$ Male $=1$, Female $=0]$ 


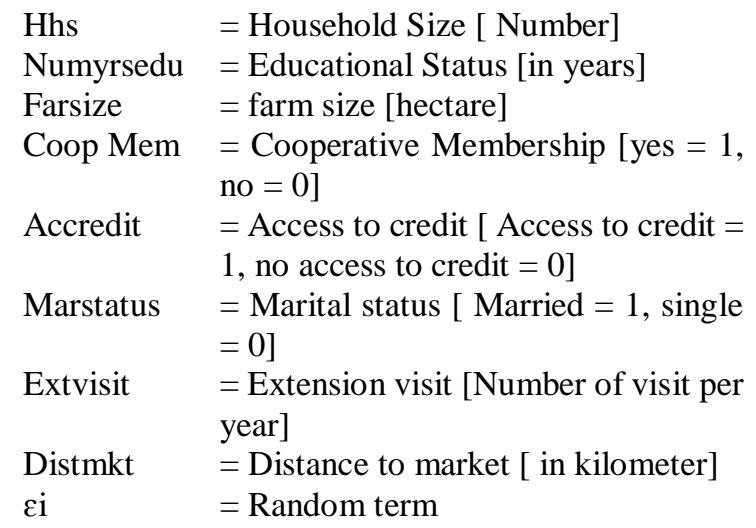

\section{RESULTS}

\section{Livelihood Activities Engage in apart from Rice} Farming

Of the 158 rice farming households engaged in two or more livelihoods, the most preferred activity is livestock production $(32.9 \%)$, followed by other food crops $(17.7 \%)$. Other activities undertaken to complement rice farming include cash crops (15.2\%), natural resources such as fishing (12.7\%), agricultural wage $(10.8 \%)$, non-agricultural wage $(8.9 \%)$ and others (1.8\%). It was observed that most of the rice farmers keep some livestock in abide to diversify their livelihood. 8.9 percent of the rice farming households earn income from nonagricultural employments. This finding is in line with the findings of Warren's (2002) perspective on rural diversification alternatives.

Table 1. Distribution of Respondents by Livelihood Activities Engage in apart from Rice Farming

\begin{tabular}{lrr}
\hline Activities & Frequency & Percent $\%$ \\
\hline Livestock keeping & 52 & 32.9 \\
Other food crops & 28 & 17.7 \\
Cash crops & 24 & 15.2 \\
Natural resources & 20 & 12.7 \\
Agricultural wage & 17 & 10.8 \\
Non-agricultural & 14 & 8.9 \\
wage & & \\
Others & 3 & 1.8 \\
Total & 158 & 100.0 \\
\hline Source: Field survey (2019) & &
\end{tabular}

Total Household Income and Share of Farm and Non-Farm Income

The result of this computation is represented in Table 2

Share of Farm Income (SFI)

Share of Farm Income (SFI) was $75.91 \%$. In this category, Food crops income source dominated with income share of $39.46 \%$. Cash crops income share was $16.20 \%$. The low share of cash crop income is as result of the fact that, the farmers cropped more of food crops compared to cash crops. Livestock represented $6.03 \%$, natural resources collection incomes shares was $1.65 \%$, while farm wage income was $12.57 \%$. Thus, in total, the farm income share represents $75.91 \%$ of total household income. The results indicate the importance of farming and it is related activities to the rice farmers.

\section{Share of Non-Farm Income (SNFI):}

Non-farm Income (NFI) represented $24.09 \%$ of the total income of the rice farmers. Non-farm wage income dominated the Non-farm income category, Self-employment income had the smallest share of $2.95 \%$, Remittances was $3.8 \%$.

In total, the Share of Non-farm income in THI was found to be $24.09 \%$. This is lower than the share of income generated from the farm sector by the farming households.

This finding on the shares of income coming from farm and Non-farm sources is in line with the findings of Schwarze and Zeller (2005) who found larger shares of farm income of $68 \%$ and $32 \%$ respectively for Indonesia households. However, the finding is contrary to the works of Idowu et al. (2011), who found $32.92 \%$ share of farm income in total household income and $67.08 \%$ of Non-farm income amongst rural farm households in southern Nigeria.

Table 2. Share of Farm and Non-Farm Income in Total Household Income

\begin{tabular}{lrr}
\hline Income sources & $\begin{array}{r}\text { (\%) Share of } \\
\text { Total } \\
\text { income }\end{array}$ & Value (N) \\
\hline Food crop & 39.46 & $135,692.45$ \\
Cash crop & 16.20 & $55,707.49$ \\
Livestock & 6.03 & $20,735.57$ \\
Natural & 1.65 & $5,673.91$ \\
Resources & & \\
Income & & \\
Farm Wage & 12.57 & $43,224.89$ \\
Income & & \\
Share of Farm & 75.91 & $261,034.31$ \\
Income (SFI) & & \\
Non- Farm wage & 17.56 & $60,384.17$ \\
Income & & \\
Self-employed & 2.95 & $10,144.27$ \\
income & & \\
Remittance & 3.58 & $12,310.67$ \\
Share of Non- & 24.09 & $82,839.11$ \\
farm Income & & \\
(SNFI) & & \\
$\quad$ Total & 100.0 & $343,873.42$ \\
\hline Source: Field survey (2019) & & \\
\hline
\end{tabular}

Rice Farmer Livelihood Diversification Indices Table 3 shows the distribution of livelihood diversification indices of the rice farmers obtained by Simpson's index of diversification. The Simpson Index of Diversification (SID) results revealed that the farm sector continues to be vital to rice farm households in the study area. As the value of SID 
moves closer to one, the more diversified the household's livelihood is. A mean degree of diversification of $0.52(52.3 \%)$ was found among rice farming households in the study area.

The relatively high degrees of diversification recorded by rice farming households in the study area could be attributed to the operations of other activities in this area which promoted non-farm business activities. The high degree of the diversification recorded is in line with FAO (2008), which opined that a large majority of rural households are engaged in some agricultural activity, but many derived a large part of their income from non- farm activities and transfers. Individuals participated in a wide range of occupations, but occupational diversity does not necessarily translate into significant income diversity in households. This is also in accordance with the work of Babatunde and Qaim (2009).

Table 3. Distribution of Respondents by Livelihood Diversification Indices

\begin{tabular}{ccr}
\hline Range & Frequency & Percent $\%$ \\
\hline $0-0.1$ & 2 & 1.3 \\
$0.11-0.2$ & 1 & 0.6 \\
$0.21-0.3$ & 2 & 1.3 \\
$0.31-0.4$ & 13 & 8.3 \\
$0.41-0.5$ & 2 & 1.3 \\
$0.51-0.6$ & 22 & 13.9 \\
$0.61-0.7$ & 30 & 19.0 \\
$0.71-0.8$ & 76 & 48.1 \\
$0.81-0.9$ & 10 & 6.3 \\
$0.91-1.0$ & 0 & 0.0 \\
Total & 158 & 100.0 \\
\hline
\end{tabular}

Source: Field Survey (2019)

Respondents Awareness and Adoption of Production Technologies

Table 4 shows the distribution of respondents by awareness and adoption of production technologies involved in rice production. The land preparation involves tractor pulled implement and bulldozer for bush clearing. It was deduced from Table 4.4 that
57.6 percent of the rice farmers had tried tractor pulled implement but never adopted it. Only 13.9 percent adopted this technology. Regarding use of bulldozer for bush clearing none of the rice farming households adopted this, 29.1 percent of the respondents adopted the mechanized ploughing while 56.3 percent were not aware of this type of technology. This may be due to lack of information on the benefit of this technology to the farmers in the study area. For mechanized harrowing only a few (7.6) percent of the rice farmers adopted it. A huge (64.6) percent of them had tried it but are yet to adopt. Majority (72.2\%) of the rice farmers had tried but not adopted the mechanized ridging while only $13.3 \%$ had adopted it. It was observed that only 7.6 percent of the rice farmers adopted the seed broadcaster technology, 43.0 percent of the respondents used the improved planting method, while none of the farmers adopted the rice seed planter. In maintaining the rice farm, very few $(7.6 \%)$ of the farmers adopted mechanized weeding, 43.7 percent used herbicides, most (71.5) percent adopted the use of inorganic fertilizer. This may be due to fast release of mineral nutrient to the soil. Some 63.9 percent of the rice farmers adopted the knapsack/boom sprayer technology. Very few of them $(7.6 \%)$ adopted the use of organic fertilizer, 36.1 percent adopted the use of pest scaring devices, while 51.3 percent used pesticides (mammal, insects, aves, etc). None of the farmers adopted the water management technology.

Also, from Table 4 only 15.2 percent of the farmers adopted the grain harvester, while 7.6 percent adopted the combine harvester technology. These findings are in line with the findings of Yaron et al. (1998) and Harper et al. (1998) which found that small farm households have a negative correlation between adoption of new technology and land size of small farm households. Also, Bola et al. (2012) revealed that technology complexity has a negative impact on adoption of technologies and this bottle neck could only be solved through education.

Table 4. Distribution of the Respondents by Awareness and Adoption Technology in Rice Production

\begin{tabular}{lrrrr}
\multicolumn{1}{c}{ Technology } & Not Aware & $\begin{array}{c}\text { Aware but Never } \\
\text { Tried }\end{array}$ & $\begin{array}{c}\text { Tried but Not } \\
\text { Adopted }\end{array}$ & Adopted \\
\hline $\begin{array}{l}\text { Land clearing } \\
\text { Tractor pulled } \\
\text { implement (tillage) }\end{array}$ & $45(28.5)$ & $0(0.00)$ & $91(57.6)$ & $22(13.9)$ \\
$\begin{array}{l}\text { Bulldozer for Bush } \\
\text { Clearing }\end{array}$ & $103(65)$. & $21(13.3)$ & $34(21.5)$ & $0(0.00)$ \\
$\begin{array}{l}\text { Land preparation } \\
\text { Mechanized ploughing }\end{array}$ & & & & \\
Mechanized harrowing & $89(56.3)$ & $12(7.6)$ & $11(7.0)$ & $46(29.1)$ \\
& $21(13.3)$ & $23(14.6)$ & $102(64.6)$ & $12(7.6)$ \\
\hline
\end{tabular}




\begin{tabular}{|c|c|c|c|c|}
\hline Technology & Not Aware & $\begin{array}{c}\text { Aware but Never } \\
\text { Tried }\end{array}$ & $\begin{array}{l}\text { Tried but Not } \\
\text { Adopted }\end{array}$ & Adopted \\
\hline Mechanized ridging & $11(7.0)$ & $12(7.6)$ & $114(72.2)$ & $21(13.3)$ \\
\hline \multicolumn{5}{|l|}{ Planting } \\
\hline Seed Broadcaster & $76(48.1)$ & $24(15.2)$ & $46(29.1)$ & $12(7.6)$ \\
\hline Seed of improved Rice & $56(35.4)$ & $22(13.9)$ & $12(7.6)$ & $68(43.0)$ \\
\hline Seed Planter (Rice) & $43(27.2)$ & $68(43.0)$ & $47(29.7)$ & $0(0.0)$ \\
\hline \multicolumn{5}{|l|}{ Post planting } \\
\hline Mechanized weeding & $102(64.6)$ & 33 (20.9) & $11(7.0)$ & $12(7.6)$ \\
\hline Herbicides & $0(0.0)$ & $34(21.5)$ & $55(34.8)$ & $69(43.7)$ \\
\hline Inorganic Fertilizer & $0(0.0)$ & $12(7.6)$ & 33 (20.9) & $113(71.5)$ \\
\hline Knapsack/Boom & $\begin{array}{ll}0 & (0.0)\end{array}$ & $23(14.6)$ & $34(21.5)$ & $101(63.9)$ \\
\hline \multicolumn{5}{|l|}{ Sprayer } \\
\hline Organic Fertilizer & $11(7.0)$ & $88(55.7)$ & 47 (29.7) & $12(7.6)$ \\
\hline Pest Scaring Devices & $44(27.8)$ & $46(29.1)$ & $11(7.0)$ & $57(36.1)$ \\
\hline $\begin{array}{l}\text { Pesticides (Mammal, } \\
\text { Insect, Aves, etc) }\end{array}$ & $33(20.9)$ & $10(6.3)$ & $34(21.5)$ & $81(51.3)$ \\
\hline Modernized scare scroll & $46(29.1)$ & $34(21.5)$ & 33 (20.9) & 45 (28.5) \\
\hline Water & $67(42.4)$ & $59(37.3)$ & $32(20.3)$ & $0(0.0)$ \\
\hline \multicolumn{5}{|l|}{ Management/Irrigation } \\
\hline \multicolumn{5}{|l|}{ Equipment } \\
\hline \multicolumn{5}{|l|}{ Harvest } \\
\hline Grain Harvester & $55(34.8)$ & $68(43.0)$ & $11(7.0)$ & $24(15.2)$ \\
\hline Combine Harvester & $67(42.4)$ & $47(29.7)$ & $32(20.3)$ & $12(7.6)$ \\
\hline
\end{tabular}

Source: Field Survey (2019)

Table 5: Distribution of Respondents by Awareness and Adoption of Post-Harvest Technology

\begin{tabular}{lrrrr}
\hline \multicolumn{1}{c}{ Technology } & Not Aware & $\begin{array}{c}\text { Aware but Never } \\
\text { Tried }\end{array}$ & $\begin{array}{c}\text { Tried but Not } \\
\text { Adopted }\end{array}$ & \multicolumn{1}{c}{ Adopted } \\
\hline De-stoner & $78(49.4)$ & $36(22.8)$ & $22(13.9)$ & $22(13.9)$ \\
Grading machine & $76(48.1)$ & $47(29.7)$ & $24(15.2)$ & $11(7.0)$ \\
Milling machine & $0(0.0)$ & $23(14.6)$ & $0(0.0)$ & $135(85.4)$ \\
Packaging machine & $69(43.7)$ & $33(20.9)$ & $56(35.4)$ & $0(0.0)$ \\
Parboiler & $0(0.0)$ & $11(7.0)$ & $23(14.6)$ & $124(78.4)$ \\
Polisher & $88(55.7)$ & $59(37.3)$ & $11(7.0)$ & $0(0.0)$ \\
Rice cleaner & $79(50.0)$ & $45(28.5)$ & $11(7.0)$ & $23(14.6)$ \\
Rotary dryer & $79(50.0)$ & $45(28.5)$ & $11(7.0)$ & $23(14.6)$ \\
Shelling machine & $79(50.0)$ & $57(36.1)$ & $11(7.0)$ & $11(7.0)$ \\
Steamer & $135(85.4)$ & $23(14.6)$ & $0(0.0)$ & $0(0.0)$ \\
\hline
\end{tabular}

Source: Field Survey (2019)

\section{Awareness and Adoption of Post-Harvest Technologies}

It was observed from Table 5 that a few (13.9) percent of the respondents adopted the De-stoner technology. This may be due to the unavailability of the technology in the study area. Some 7.0 percent of rice farming households used grading machines. Majority $(85.4 \%)$ of the rice farmers adopted the milling machine. None of the respondents used packaging technology. A huge (78.4) percent of the rice farming households adopted parboiler technology. None of the rice farming households adopted polisher, and steamer technologies. Some
14.6 percent of the respondents adopted the rice cleaner and rotary dryer respectively. Only 7.0 percent used shelling technology.

\section{Food Security Status of Rice Farming Households}

The food security status of rice farming households was categorized by age, sex, household size, educational level, marital status, number of extension agent visit per year and farming experience. The results of rice farming household food security profiled by selected socio-economic variables are presented in Table 6. 
The results showed that rice farming households whose heads were between the ranges 26-35 years had the highest incidence, lowest depth and lowest severity of food security. Rice farming household heads within this age group are at their high economic active age and are consequently expected to be more food secure than those in other age groups. This result is line with the work of Yusuf, Balogun and Falegbe (2013), who found that the older the farming household the less their food security.

Table 6 also revealed that; food security differs across socio-economic characteristics of the rice farming households. With respect to the gender of the head of the household, male headed household is less food insecure with incidence of 0.741 , depth of 0.303 and severity of 0.011 . Food security situation indices for female counterparts were 0.233 for incidence, 0.144 for depth and 0.001 for severity.

Disaggregating the respondents by household size revealed that, the incidence, depth and severity of food increases with increase in the household size, which implies that as the size of rice farming households increases, the probability of them being food secure decreases. This is in line with the work of Amaza et al. (2008), who opined that household size has a negative relationship with food security and food intake.

The level of education of rice farming households depicted that households whose heads had tertiary education had the highest food security incidence (0.78). Rice farming households whose heads had no primary education had the lowest incidence (0.12). This result is in accordance with the findings of Goni, (2011) and Titus \& Adetukumbo, (2007), who opined that education as a social capital impact positively households' ability to take good and well-informed production and nutrition decisions and enhance food security by improving household food accessibility.

The distribution of rice farming household heads by marital status shows that, farming households headed by widow are the most food insecure with the food security incidence of 0.41 . Rice farming household heads that were married were more food secure with the food security incidence of 0.65 . This is in line with the work of Yusuf et al., (2013), who opined that married household heads are likely to have larger households which are engaged in income generating activities and contributing to the income.

Furthermore, Table 6 shows that rice farmers with greater than seven times of extension visit had the highest food security incidence of 0.7. this implies that the more the contact with extension agents by rice farming households the higher the probability of been food secure.

Rice farming households with more farming experience had the highest food security incidence of 0.59 , implying that farmers with more farming experience are likely to be food secured.

Table 6. Food Security Profile by Selected SocioEconomic Variables.

\begin{tabular}{|c|c|c|c|}
\hline & $\mathrm{P}_{0}$ & $\mathrm{P}_{1}$ & $\mathrm{P}_{2}$ \\
\hline \multicolumn{4}{|l|}{ Age (in years) } \\
\hline $26-35$ & 0.647 & 0.201 & 0.029 \\
\hline $36-45$ & 0.458 & 0.211 & 0.112 \\
\hline $46-55$ & 0.311 & 0.234 & 0.135 \\
\hline 56 and above & 0.550 & 0.301 & 0.206 \\
\hline \multicolumn{4}{|l|}{ Sex } \\
\hline Male & 0.741 & 0.303 & 0.011 \\
\hline Female & 0.233 & 0.144 & 0.001 \\
\hline \multicolumn{4}{|l|}{$\begin{array}{l}\text { Household Size (in } \\
\text { numbers) }\end{array}$} \\
\hline $1-4$ & 0.455 & 0.233 & 0.164 \\
\hline $5-8$ & 0.258 & 0.186 & 0.111 \\
\hline 9 and above & 0.127 & 0.012 & 0.009 \\
\hline $\begin{array}{l}\text { Educational Status } \\
\text { (in years) }\end{array}$ & & & \\
\hline $\begin{array}{l}\text { No Primary } \\
\text { education }\end{array}$ & 0.115 & 0.012 & 0.025 \\
\hline Primary education & 0.338 & 0.123 & 0.059 \\
\hline Secondary education & 0.576 & 0.100 & 0.103 \\
\hline Tertiary education & 0.777 & 0.203 & 0.112 \\
\hline \multicolumn{4}{|l|}{ Marital Status } \\
\hline Married & 0.652 & 0.200 & 0.041 \\
\hline Single & 0.518 & 0.112 & 0.023 \\
\hline Widow & 0.412 & 0.109 & 0.010 \\
\hline \multicolumn{4}{|l|}{$\begin{array}{l}\text { Extension Visit } \\
\text { (number of visit/year) }\end{array}$} \\
\hline $1-3$ & 0.542 & 0.025 & 0.012 \\
\hline $4-6$ & 0.572 & 0.039 & 0.028 \\
\hline 7 and above & 0.701 & 0.045 & 0.033 \\
\hline \multicolumn{4}{|l|}{$\begin{array}{l}\text { Farming Experience } \\
\text { (in years) }\end{array}$} \\
\hline $1-2$ & 0.421 & 0.113 & 0.011 \\
\hline $3-4$ & 0.488 & 0.220 & 0.016 \\
\hline $5-6$ & 0.522 & 0.231 & 0.019 \\
\hline 7 and above & 0.591 & 0.245 & 0.021 \\
\hline
\end{tabular}

Source: Field Survey, (2019). Po, $\mathrm{P}_{1}$ and $\mathrm{P}_{2}$ represent food security incidence, depth and severity respectively.

Effect of Livelihood Diversification and Technology Adoption on Food Security Status of Rice Farmers

Table shows the effect of livelihood diversification and technology adoption on food security status of the rice farmers. It was observed that the coefficient of Simpson Index of Diversification (SID), the Technologies Adoption Index (TA), household size, 
educational status of the farmers, farm size and access to credit are all significant and positive at 5\% level of significance. Household size coefficient too was significant but had a negative sign.

The coefficient of Simpson Index of Diversification (SID)was significant and positive which implies that an increase in the livelihood diversification of rice farmers will reduce their food insecurity. This is in line with the work of Raphael et al., (2017) which says that increasing the number of livelihoods means engaged in by a household, increase income level and consequently lead towards food security. It is therefore worthy to note that livelihood diversified households are more income stable and food secured than the reverse households.

The technologies adoption coefficient was also observed to be positive and significant, which means that a unit increase on technologies adoption will lead an increased in food security status of the rice farmers in the study area. This is in line with the work of Obisesan and Omonona (2013) which revealed the impact of the RTEP improved production technology on the food insecurity incidence, depth and severity of beneficiaries. The food insecurity incidence of RTEP reduced by

Table 7. The Effect of Livelihood Diversification and Technology Adoption on Food Security Status of the Rice

\begin{tabular}{|c|c|c|c|c|}
\hline Variables & Coefficient & Std.Error & Marginal effect & t-value \\
\hline Constant & $1.992 * *$ & 0.968 & & 2.059 \\
\hline Simpson Index of Diversification & $0.320 * * *$ & 0.088 & 0.037 & 3.636 \\
\hline Technology Adoption & $1.019 * *$ & 0.470 & 0.271 & 2.168 \\
\hline Age & 0.006 & 0.013 & 0.018 & 0.478 \\
\hline Sex & 0.099 & 0.157 & 0.067 & 0.633 \\
\hline Household Size & $-0.060 *$ & 0.031 & -0.599 & -1.935 \\
\hline Educational Status & $0.035^{* *}$ & 0.012 & 0.028 & 2.917 \\
\hline Farm Size & $0.133 * * *$ & 0.040 & 0.002 & 3.306 \\
\hline Cooperative Membership & 0.259 & 0.203 & 0.245 & 1.279 \\
\hline Access to Credit & $0.405 * *$ & 0.186 & 0.449 & 2.183 \\
\hline Marital Status & .024 & .066 & 0.243 & 0.370 \\
\hline Extension Visit & .048 & .038 & 0.077 & 1.267 \\
\hline Distance to market & -.010 & .021 & 0.029 & -0.474 \\
\hline
\end{tabular}

$\mathrm{R}^{2}=0.69$

Adj. $R^{2}=0.56$

Number of cases predicted correctly $147(93.0 \%)$

Source: Field Survey (2019). *** significant at 1\%, **significant at 5\%, *significant at $10 \%$.

\section{CONCLUSION}

The study revealed that income from non-farm activities such as self- employment in nonagricultural activities play a huge role in the livelihood diversification of the rice farmers.

The rice farmers education in the study area was one of the major factors needed to improve their skills on other form of livelihood in order to enhance their
$16.27 \%, 12.02 \%$ and $21.54 \%$ when compared with ANRTEPB, NRTEPBW and NRTEPBO respectively.

Due to spillover effect of the programme, the impact was deeper on FGT food insecurity indices of RTEPB when compared with the NRTEPBO than when compared with NRTEPBW. The result also shows that food insecurity gap and the severity of food insecurity indices dropped when compared with non-beneficiaries. The food insecurity gap of RTEPB dropped by $25.11 \%, 22.56 \%$ and $45.69 \%$ while the food insecurity severity reduced by $33.06 \%, 31.69 \%$ and $50.82 \%$ when compared with ANRTEPB, NRTEPBW and NRTEPBO respectively.

The household size coefficient was found to be negative and significant, which implied that as household increase in size, there is tendency for the household to be food insecure. The coefficients of educational status, farm size and access to credit were found to be positive and significant at 5\%, 5\% and $10 \%$ probability levels respectively. This signifies that an increase in these variables will lead to an increase in level of food security of the rice farmers. 


\section{RECOMMENDATIONS}

The following recommendations are made from the study.

1. Rice farmers should be encouraged to diversify their livelihood so as to be food secure.

2. The farmers should be educated on modern technologies in the production of rice.

3. Rice farming households should be encouraged and assisted by providing the necessary technologies needed for rice production.

4. Rice farming households be encouraged to increase the size of their farms thereby increasing their food security status.

5. Credit facilities should be made available for the rice farming household either by the government or private sectors to enhance farming activities, increase farm size, alleviate poverty and make the farmers food secured.

\section{REFERENCES}

Adebayo, O. O. (2012). Effects of Family Size on Household Food Security in Osun State, Nigeria. Asian Journal of Agriculture and Rural Development. 2(2), 136-14.

Adenegan, K.O. and Adewusi, O.A. (2007). Determinants of Food Security Status of Rural Households Living With HIV/AIDS in Southwestern Nigeria. African Journal of Biomedical Research. 10: 9-18.

Agu, P. (2013). Rural Non-farm Livelihood Diversification and Poverty Reduction in Nigeria. School of Management, University of Plymouth, U.K.

Akande, S. O., (2002). An overview of the Nigerian Rice economy. Available at: http://www.unep.ch/etu/etp/events/agricultu re/nigeria.pdf

Amaza, P.S., Adejobi, A.O. and Fregene, T., (2008). Measurement and Determinants of Food Insecurity in Northeast Nigeria: Some Empirical Policy Guidelines. Journal of Food, Agriculture \& Environment. 6(2). 92-96.

Arene, C.J. and Anyaeji, M.R. (2010). Determinants of Food Security among Households in Nsukka Metropolis of Enugu State, Nigeria. Pakistan Journal of Social Sciences (PJSS), 30(1): 9-16.

Asmah, E. (2011). "Rural Livelihood Diversification and Agricultural Household Welfare in Ghana." Journal of Development and Agricultural Economics 3(7):325-334.
Ayalew A.M. (2011). Factors Affecting Adoption of Improved Haricot Bean Varieties and Associated Agronomic Practices in Dale Woreda, SNNPRS. Unpublished M.Sc. Thesis submitted to the Department of Plant and Horticultural Sciences, College of Agriculture, Hawassa University, Hawassa, Ethiopia. Accesses online Jan. 10, 2016 https://cgspace.cgiar.org/bitstream/handle/1 0568/10291/FinalThesis_AlemituMulugeta. pdf?sequence $=1 \&$ is Allowed $=y$

Babatunde R. O. and Qaim, M. (2010). Impact of Off-Farm Income on Food Security and Nutrition in Nigeria. Food Policy 35: 303311.

Babatunde, R.O., Omotesho, O.A. and Sholotan, O.S. (2007), "Socio-Economics Characteristics and Food Security Status of Farming Households in Kwara State, North Central Nigeria". Pakistan Journal of Nutrition. 6(1): 49-58.

Barla, M. (2013). The Impact of New Agricultural Technology on Tribal Farming: A Study of Ranchi District of Jharkhand State. Journal of Economic \& Social Development. 9: 121-131.

Barrett, C.B. and Reardon, T. (2000). Asset, Activity, and Income Diversifications among African Agriculturalist: Some Practical Issues. Project report to USAID BASIS CRSP, March 2000.

Bola AA, Aliou D, Omonona BT (2012). Impact of improved agricultural technology adoption on sustainable Rice productivity and Rural Farmers $^{\text {ee }}$ welfare in Nigeria: A local Average Treatment Effect ( ATE) Technique.

Boto, I. (2014). Realizing the Promise of Agriculture for Africa's Transformation. Brussels.

Dimova, R. and Sen, K. (2010): Is Household Income Diversification a Means of Survival or a Means of Accumulation? Panel data evidence from Tanzania. Brooks World Poverty Institute Working Paper 122: 1-34. Manchester.

Ellis, F. (2000). Rural Livelihood and Diversity in Developing Countries. Oxford: Oxford University Press.

Enterprise Development Sub-Programme. Available at: ftp://ftp.fao.org/docrep/fao/008/j2816e/j281 6e00.pdf (Accessed 11 April 2014). 
exploration of concepts and issues. FAO, LSPWP 4, Livelihoods diversification and

FAO (2017). FAO Cereal Supply and Demand Brief.

http://www.fao.org/worldfoodsituation lcsdb/en/

FAO, WFP and IFAD (2015). The State of Food Insecurity in the World 2014: Strengthening the Enabling Environment for Food Security and Nutrition. Rome: FAO.

Goni, M., (2011). Household Food Security Situation, Determinants and Coping Strategies in Borno State, Nigeria. A PhD Thesis Submitted to Usmanu Danfodiyo University, Sokoto.

Haggblade, S., and Hazell, P. (2010). Successes in African agriculture: Lessons for the future. John Hopkins University Press.

Harper JK, Rister ME, Mejelde JW, Drees BM, and Way MO (1998). Factors Influencing the Adoption of Insect Management Technology. Am. J. Agric. Econ. 72(4):9971005.

Hassan, K. (2015). Resources Management and Risk Efficiency of Crop Rotation. Canadian Center of Science and Education. Sustainable Agriculture Research. 4 (4); 2015

Hazell, P. (2011). Five Big Questions About Five Hundred Million Small Farmers. Paper Presented at the IFAD Conference on New Directions for Smallholder Agriculture. Rome: IFAD.

Idowu, A.O., Aihonsu, J.O.Y, Olubanjo, O.O. and Shitu, A.M. (2011): 'Determinants of Income Diversification amongst Rural Farm Households in South West Nigeria'. In: Eonomics and Finance Review. 1 (5): 31-43.

Igbokwe, E. M. (2001). Adoption of Rice Production Techniques among Wetland Farmers in Southeastern Nigeria. Tropicultura 19(4):180-183.

Korir, L. K., Legat, K. J. and Njehia B. K. (2005): The Role of Non-Farm Investments in Agricultural Risk Management in Kenya, current research. In: Journal of Economic Theory 3 (2): 62-68.

Lay, J. and D. Schuler (2008). Income Diversification and Poverty in A Growing Agricultural Economy: The Case of Ghana. Proceedings of the German Development Economics Conference, Zurich. 39: 1-39.
Mihiretu, T. A., (2008). Farmers Evaluation and Adoption of Improved Onion Production Package in Fogera District, South Gondar, Ethiopia. Unpublished M.Sc. Thesis Presented to The School of Graduate Studies Haramaya University, Ethiopia. Accessed online Jan. $10, \quad 2016$ https://cgspace.cgiar.org/bitstream/handle/1 0568/683/Thesis_AdgoFarmers. pdf?sequence $=1 \&$ is Allowed $=\mathrm{y}$

Minot, N., M. Epprecht, T.T.T. Anh and Q.L. Trung (2006): Income Diversification and Poverty in the Northern Uplands of Vietnam. IFPRI Research Report (145), 1111. Washington, D.C.

National Population Commission (2006)

Obayelu, A. E., Okuneye, P. A., Shittu, A. M., Afolami, C. A. and Dipeolu, A. O. (2016). 'Determinants and the Perceived Effects of Adoption of Selected Improved Food Crop Technologies by Smallholder Farmers along the Value Chain in Nigeria.' Journal of Agriculture and Environment for International Development. 110 (1):155 172

Obisesan A.A. and Omonona B.T. (2013). 'The Impact of RTEP Technology Adoption on Food Security Status of Cassava-Farming Households in Southwest, Nigeria.' Greener Journal of Agricultural Sciences. 3(6): 469475

Okeke, E. C., Enebong H. N., Uzuegbunam, A. O., Ozioko, A. O. and Kuhnlein, H, (2008). Igbo traditional Food system: Documentation, Uses and Resaerch Needs. Pak. J. Nutr. 7(2): 365-376.

Omonona B.T., Lawal J.O. and Oyebiyi I.D. (2012). "Profitability of Production and Resource Use Efficiency among Ofada Rice (Oryza sativa japonica) Farmers in Southwest, Nigeria." Comunicata Scientiae 3 (2): 104107.

Oni, O.A., K. K. Salman and B.O. Idowu. (2011). "Social Capital Dimension and Food Security of Farming Households in Ogun State, Nigeria." Journal of American Science. 7(8): 776- 783.

Onimawo, I. (2012). Traditional Food Systems in Assuring Food Security in Nigeria. In Burlingame B. Demini S. (eds) Sustainable Diets for Biodiversity. Directions and Solutions for Policy, Research and Action. Proceedings of the International Scientific Symposium on Biodiversity and Sustainable Diets United against Hunger. 3-5 FAO 
Rome.

Raphael Ndubuisi, E., Chigozirim, N., Onwusiribe, D. and Chinedu N. (2017). Effect of Livelihood Diversification on Food Security Status of Rural Farm Households in Abia State Nigeria. 'Scientific Papers Series Management, Economic Engineering in Agriculture and Rural Development' 17(1): 159-166.

Ronning, L. and L. Kolvereid (2006). Income Diversification in Norwegian Farm households, Reassessing Pluriactivity. In: International Small Business Journal 24 (4): 405419.

RPR (2011) (Rural Poverty Report). New Realities, New Challenges: New Opportunities for Tomorrow's Generation. Rome.

Schwarze, S. and Zeller, M. (2005): Income Diversification of Rural Households in Central Sulawesi, Indonesia. In: Quarterly Journal of International Agriculture’ 44 (1): 61-73.

Stifel, D. (2010). "The Rural Non-Farm Economy, Livelihood Strategies and Household Welfare." African Journal of Agricultural Research 4 (1): 82-109.
Titus, B. and Adetokunbo, G. (2007). An Analysis of Food Security Situation among Nigerian Urban Households: Evidence from Lagos State, Nigeria. Journal of Central European Agriculture. 8(3): 397-406.

UNECA (2013). Assessing Progress in Africa towards the Millenium Development Goals. Food security in Africa: Issues, challenges and lessons. The United Nations Economic Commission for Africa (ECA).

Warren P. (2002). Livelihoods diversification and enterprise development: an initial

Yaron, A., Hutzubal, A., Davis, M., Lavon, I., Amit, S., Manning, A. M., Anderson, J. S., Mann, M. and Ben, N. Y. (1998). Identification of the Receptor Component of the IkbaUbiquitinligase. Nature. 396.

Yusuf, S. A., Balogun, O. L. and Falegbe, O. E. (2013). Effect of Urban Household Farming on Food Security Status in Ibadan Metropolis, Oyo State, Nigeria. Journal of Agricultural Sciences. 60 (1): 61-75 